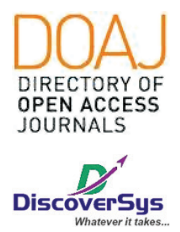

Published by DiscoverSys

\title{
Gambaran prediktor perforasi pada penderita apendisitis di Rumah Sakit Umum Ari Canti Gianyar, Bali, Indonesia tahun 2018
}

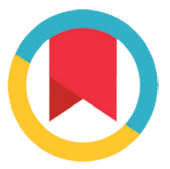

CrossMark

\author{
Cokorda Bagus Nurparma Putra, ${ }^{1 *}$ Sang Nyoman Suryana ${ }^{2}$
}

\section{ABSTRACT}

Background: Acute appendicitis is one of the most common acute abdomen disease. Morbidity and mortality increased when the complications occur. The most severe complication is perforation which can cause peritonitis and sepsis. So it needs to be known as early as possible to prevent deterioration. This study aims to determine the predictor factors of perforation in appendicitis.

Method: This study was retrospective cross sectional design using secondary data from medical records of appendicitis patients treated at Aricanti Hospital, Gianyar in 2018. Total samples are 96 and they were selected by consecutive technique sampling. Data about age, sex, Total Leukocyte Count (TLC), and symptoms duration of appendicitis patients were collected and analyzed using the Chi-square test.
Result: From 96 samples, 33 (34.4\%) were perforated appendicitis and 63 (65.6\%) were acute appendicitis. Chi-square test results showed that the predictor factors associated with perforated appendicitis were age under 10 and above 49 years $\left(P R=2.0 ; X^{2}=5.474 ; p<0.05\right)$, male more affected than females $\left(X^{2}=8.800 ; p<0.05\right)$, TLC more than $18000 / \mathrm{mm}^{3}\left(P R=3.3 ; X^{2}=20.862 ; p<0.05\right)$ and symptoms duration above 24 hours $\left(P R=4.1 ; X^{2}=24.834 ; p<0.05\right)$.

Conclusion: Age, sex, TLC, and symptoms duration can be used as predictors for perforated appendicitis. These predictor factors should be evaluated in appendicitis patients to prevent the occurrence of perforation or to provide immediate treatment in cases of perforation.

Keywords: appendicitis, perforation, predictor factor.

Cite This Article: Putra, C.B.N., Suryana, S.N. 2020. Gambaran prediktor perforasi pada penderita apendisitis di Rumah Sakit Umum Ari Canti Gianyar, Bali, Indonesia tahun 2018. Intisari Sains Medis 11(1): 122-128. D0I: 10.15562/ism.v11i1.575

ABSTRAK

Latar Belakang: Apendisitis akut merupakan salah satu akut abdomen yang paling sering dijumpai. Peningkatan morbiditas dan mortalitas terjadi bila terjadi komplikasi. Komplikasi yang terberat adalah perforasi apendiks yang dapat menyebabkan peritonitis dan sepsis. Sehingga perlu diketahui sedini mungkin untuk mencegah perburukan. Penelitian ini bertujuan untuk mengetahui faktor prediktor perforasi pada kasus apendisitis.

Metode: Penelitian ini berdesain retrospektif cross sectional dengan menggunakan data sekunder berupa rekam medis pasien apendisitis yang dirawat di RSU Aricanti Gianyar tahun 2018. Sampel pada penelitian ini berjumlah 96 yang dipilih secara consecutive sampling. Data mengenai usia, jenis kelamin, Total Leukosit Count (TLC), dan symptoms duration pasien apendisitis dikumpulkan dan dianalisa menggunakan uji Chi-square.
Hasil: Dari 96 sampel, sebanyak 33 (34,4\%) merupakan apendisitis perforasi dan $63(65,6 \%)$ merupakan apendisitis akut. Hasil uji Chi-square menunjukan faktor prediktor yang berhubungan dengan apendisitis perforasi adalah usia dibawah 10 dan diatas 49 tahun $\left(P R=2,0 ; X^{2}=5,474 ; P<0,05\right)$, jenis kelamin laki laki $\left(X^{2}=8,800\right.$; $\mathrm{p}<0,05)$, TLC lebih dari $18000 / \mathrm{mm}^{3}\left(P R=3,3 ; X^{2}=20,862 ; p<0,05\right)$ dan symptoms duration diatas 24 jam $\left(P R=4,1 ; X^{2}=24,834\right.$; $\mathrm{p}<0,05)$

Simpulan: Berdasarkan hasil uji statistik tersebut dapat disimpulkan bahwa usia, jenis kelamin, TLC, dan symptoms duration dapat dijadikan faktor prediktor terjadinya apendisitis perforasi. Faktor prediktor ini sebaiknya diperhatikan untuk mencegah kejadian perforasi pada pasien apendisitis ataupun memberikan penanganan yang lebih cepat pada kasus perforasi.
Fakultas Kedokteran, Universitas Udayana, Denpasar, Bali, Indonesia ${ }^{2}$ Bagian Bedah Umum Rumah Sakit Umum Ari Canti, Gianyar, Bali, Indonesia

${ }^{*}$ Correspondence to: Cokorda Bagus Nurparma Putra, Fakultas Kedokteran, Universitas Udayana, Denpasar, Bali, Indonesia baguscokorda@gmail.com

Diterima: 29-07-2019

Disetujui: 06-01-2020

Diterbitkan: 05-03-2020
Kata kunci: Apendisitis, perforasi, faktor prediktor

Cite Pasal Ini: Putra, C.B.N., Suryana, S.N. 2020. Gambaran prediktor perforasi pada penderita apendisitis di Rumah Sakit Umum Ari Canti Gianyar, Bali, Indonesia tahun 2018. Intisari Sains Medis 11(1): 122-128. D0I: 10.15562/ism.v11i1.575

\section{PENDAHULUAN}

Apendisitis adalah suatu keadaan inflamasi akibat adanya obstruksi pada lumen apendiks oleh fecaliths atau akibat hiperplasia limpoid yang dapat memicu timbulnya inflamasi. Apendisitis merupakan kejadian yang paling banyak membutuhkan operasi emergency. ${ }^{1}$ Apendisitis menyerang 10 juta 
penduduk Indonesia setiap tahunnya dan morbiditas apendisitis di Indonesia mencapai 95 per 1000 penduduk dimana angka ini merupakan angka tertinggi apendisitis diantara negara ASEAN. ${ }^{2}$ Data Rumah Sakit Umum Sanglah Denpasar pada tahun 2006 menyatakan bahwa terdapat 470 kasus apendisitis akut. ${ }^{3}$ Berdasarkan studi di Swedia yang dilakukan oleh Pieper dan Kager memperkirakan bahwa kejadian kasus apendisitis tahunan adalah 1.33 per seribu penduduk laki-laki dan 0,99 per seribu penduduk perempuan. ${ }^{4}$

Apendisitis merupakan suatu peradangan apendiks yang berbahaya karena dapat menyebabkan komplikasi yaitu pecahnya lumen usus atau perforasi yang nantinya dapat menyebabkan peritonitis ataupun sepsis sehingga meningkatkan angka morbiditas dan mortalitas. ${ }^{5}$ Persentase komplikasi apendisitis seperti perforasi dan peritoneal abscess, khususnya pada anak-anak sebesar $30-74 \%$ dan dapat meningkatkan morbiditas serta mortalitas. ${ }^{6}$

Perforasi ditandai dengan nyeri abdomen yang berat serta demam dan biasanya terjadi dalam waktu 12 jam pertama pada kasus apendisitis. Salah satu faktor yang dapat meningkatkan laju terjadinya perforasi pada apendisitis yaitu diagnosis apendisitis yang sulit untuk ditegakkan pada pasien usia lanjut karena memiliki banyak kemungkinan diagnosis diferensial serta sulitnya melakukan komunikasi yang efektif. Pemeriksaan dan diagnosis yang terlambat juga dapat meningkatkan risiko terjadinya apendisitis perforasi. Adanya gejala yang tidak khas, keterlambatan penanganan, adanya arteriosklerosis dan terjadinya perubahan anatomi apendiks veriformis seperti terdapat penyempitan lumen dapat menjadi faktor yang mempengaruhi tingginya insiden apendisitis perforasi. ${ }^{2}$

Insiden kasus apendisitis perforasi pada anakanak dilaporkan sebesar $18-40 \%$. Apendisitis banyak terjadi pada laki-laki usia 10-19 tahun dan komplikasi berupa perforasi sering terjadi pada usia 0-9 tahun dan diatas 50 tahun. Berdasarkan penelitian yang dilakukan oleh Socea et al. pada tahun 2013, menyatakan bahwa dari keseluruhan pasien apendisitis yang mengalami perforasi sebanyak $69,2 \%$ adalah laki-laki dan sebanyak 30,8\% adalah perempuan. ${ }^{7}$

Kejadian apendisitis perforasi dapat diturunkan apabila dapat dideteksi lebih awal. Beberapa hasil penelitian menyatakan bahwa terdapat faktor yang dapat dijadikan prediktor terjadinya perforasi pada kasus apendisitis. Pemeriksaan Total Leucocyte Count (TLC) merupakan pemeriksaan laboratorium yang dapat dijadikan prediktor terjadinya apendisitis akut dan apendisitis perforasi. Leukositosis pada pemeriksaan laboratorium sering ditemukan pada kasus apendisitis dengan komplikasi berupa perforasi. Nilai TLC secara signifikan meningkat pada kasus apendisitis dengan perforasi yaitu lebih dari $16920 \mathrm{WBC} / \mathrm{mm}^{3}$. Studi ini juga menyatakan bahwa faktor lain yang dapat dijadikan sebagai prediktor terjadinya perforasi apendisitis adalah faktor usia, jenis kelamin, dan symptoms duration. ${ }^{7}$ Penelitian ini bertujuan untuk mengetahui prediktor terjadinya perforasi pada kasus apendisitis.

\section{METODE}

Penelitian ini merupakan penelitian analitik dengan rancangan penelitian restrospektif cross sectional. Pemilihan sampel dilakukan secara nonrandom dengan menggunakan teknik Consecutive Sampling dengan besar sampel 96 orang. Data karakteristik prediktor yaitu usia, jenis kelamin, Total Leucocyte Count (TLC) dan symptoms duration didapat melalui data sekunder dari rekam medis pasien apendisitis RSU Ari Canti. Data yang telah terkumpul dianalisis dengan statistical packagae for the social sciences (SPSS) versi 20, dan dilakukan uji hipotesis dengan menggunakan uji Chi Square.

\section{HASIL}

Berdasarkan penelitian yang telah dilakukan, diperoleh hasil bahwa dari 96 kasus apendisitis sebanyak 33 kasus $(34,4 \%)$ merupakan kejadian apendisitis perforasi. Kejadian apendisitis lebih banyak terjadi pada laki-laki yaitu sebanyak 59 orang $(61,5 \%)$, sedangkan sebanyak 37 orang $(35,4 \%)$ terjadi pada perempuan. Selain itu, pada penelitian ini diperoleh hasil bahwa kejadian apendisitis terjadi pada rentang usia 8 tahun sampai 76 tahun dengan rata-rata 31,66 tahun. Pada pemeriksaan TLC pasien apendisitis, diperoleh jumlah leukosit terendah sebesar $5100 \mathrm{WBC} / \mathrm{mm}^{3}$ dan tertinggi sebesar $30.300 \mathrm{WBC} / \mathrm{mm}^{3}$ dengan rata-rata jumlah leukosit sebesar 14.573,96 WBC/mm 3 . Symptoms duration yang dialami pasien apendisitis berkisar antara 60 menit hingga 120 jam dengan rata-rata 26 jam 36 menit. Hasil penelitian di atas tercantum pada Tabel 1.

Berdasarkan uji statistik diperoleh hasil bahwa usia berpengaruh terhadap kejadian apendisitis perforasi, dimana usia di bawah 10 tahun atau di atas 49 tahun memiliki risiko lebih besar dibandingkan dengan usia 10-49 tahun. Dari 17 kasus apendisitis dibawah umur 10 tahun atau diatas 49 tahun, sebanyak 10 kasus $(58,8 \%)$ mengalami perforasi. Sedangkan, dari 79 kasus apendisitis berusia 10-49 tahun sebanyak 23 kasus $(29,1 \%)$ mengalami perforasi. Nilai PR yang diperoleh sebesar 2,0 yang menyatakan bahwa usia berpengaruh terhadap kejadian apendisitis perforasi 2,0 kali lebih besar dibandingkan dengan kejadian apendisitis non-perforasi. Perbedaan risiko tersebut secara 
Tabel 1 Distribusi sampel berdasarkan diagnosis, jenis kelamin, usia, total leucocyte count, dan symptoms duration

\begin{tabular}{lcc}
\hline Karakteristik & Frekuensi & Persentase \\
\hline Diagnosis & 33 & $34,4 \%$ \\
Apendisitis Perforasi & 63 & $65,6 \%$ \\
Apendisitis Non-perforasi & 59 & $61,5 \%$ \\
Jenis Kelamin & 37 & $38,5 \%$ \\
Laki-laki & & \\
Perempuan & $8-76$ & \\
Usia (tahun) & $31,66(17,000)$ & \\
Minimum-maksimum & & \\
Mean (SD) & $5100-30.300$ & \\
TLC (WBC/mm3) & $14.573,96(4810,958)$ & \\
Minimum-maksimum & & \\
Mean (SD) & $1-120$ & \\
Symptoms Duration (jam) & $26,651(23,8265)$ & \\
Minimum-maksimum & & \\
Mean (SD) & & \\
\hline
\end{tabular}

Tabel 2 Hubungan usia dengan kejadian apendisitis perforasi

\begin{tabular}{lccc}
\hline & \multicolumn{2}{c}{ Apendisitis Perforasi } & \\
\cline { 2 - 3 } Faktor Usia & Ya & Tidak & Total \\
\hline Berisiko $(<10$ atau $>49$ th $)$ & $10(58,8 \%)$ & $7(41,2 \%)$ & $17(100 \%)$ \\
Tidak Berisiko $(10-49$ th) & $23(29,1 \%)$ & $56(70,9 \%)$ & $79(100 \%)$ \\
Total & $33(34,4 \%)$ & $63(65,6 \%)$ & $96(100 \%)$ \\
\hline
\end{tabular}

Tabel 3 Hubungan jenis kelamin dengan kejadian apendisitis perforasi

\begin{tabular}{lccc}
\hline & \multicolumn{2}{c}{ Apendisitis Perforasi } & \\
\cline { 2 - 3 } Faktor Jenis Kelamin & Ya & Tidak & Total \\
\hline Laki-laki & $27(45,8 \%)$ & $32(54,2 \%)$ & $59(100 \%)$ \\
Perempuan & $6(16,2 \%)$ & $31(83,8 \%)$ & $37(100 \%)$ \\
Total & $33(34,4 \%)$ & $63(65,6 \%)$ & $96(100 \%)$ \\
\hline
\end{tabular}

Tabel 4 Hubungan total leucocyte count dengan kejadian apendisitis perforasi

\begin{tabular}{lccc}
\hline & \multicolumn{2}{c}{ Apendisitis Perforasi } & \\
\cline { 2 - 3 } Faktor TLC & Ya & Tidak & Total \\
\hline Berisiko $\left(>18.000 \mathrm{WBC} / \mathrm{mm}^{3}\right)$ & $15(78,9 \%)$ & $4(21,1 \%)$ & $19(100 \%)$ \\
Tidak Berisiko $\left(\leq 18.000 \mathrm{WBC} / \mathrm{mm}^{3}\right)$ & $18(23,4 \%)$ & $59(76,6 \%)$ & $77(100 \%)$ \\
Total & $33(34,4 \%)$ & $63(65,6 \%)$ & $96(100 \%)$ \\
\hline
\end{tabular}

statistik berbeda dengan melihat nilai $\mathrm{X}^{2}$ yaitu 5,474 dan nilai $\mathrm{P}<0,05$ (Tabel 2).

Berdasarkan uji statistik diperoleh hasil bahwa jenis kelamin memiliki hubungan yang bermakna dengan kejadian apendisitis perforasi, dimana laki-laki memiliki risiko lebih besar dibandingkan dengan perempuan. Pada Tabel 3 menunjukkan kejadian apendisitis perforasi lebih banyak terjadi pada laki-laki dibandingkan dengan perempuan. Dari 59 penderita apendisitis laki-laki, sebanyak 27 orang $(45,8 \%)$ mengalami perforasi. Sedangkan, dari 37 penderita apendisits perempuan, sebanyak 6 orang $(16,2 \%)$ mengalami perforasi. Nilai PR yang diperoleh sebesar 2,8 yang menyatakan bahwa jenis 
Tabel 5 Hubungan symptoms duration dengan kejadian apendisitis perforasi

\begin{tabular}{lccc}
\hline & \multicolumn{2}{c}{ Apendisitis Perforasi } & \\
\cline { 2 - 3 } Faktor Symptoms Duration & Ya & Tidak & Total \\
\hline Berisiko (> 24 jam) & $22(71,0 \%)$ & $9(29,0 \%)$ & $31(100 \%)$ \\
Tidak Berisiko $(\leq 24$ jam) & $11(16,9 \%)$ & $54(83,1 \%)$ & $65(100 \%)$ \\
Total & $33(34,4 \%)$ & $63(65,6 \%)$ & $96(100 \%)$ \\
\hline
\end{tabular}

kelamin berpengaruh terhadap kejadian apendisitis perforasi 2,8 kali lebih besar dibandingkan dengan kejadian apendisitis non-perforasi. Perbedaan risiko tersebut secara statistik berbeda dengan melihat nilai $\mathrm{X}^{2}$ yaitu 8,800 dan nilai $\mathrm{P}<0,05$.

Hasil uji statistik menunjukkan adanya pengaruh antara TLC dengan kejadian apendisitis perforasi yaitu kadar TLC $>18.000 \mathrm{WBC} / \mathrm{mm}^{3}$ berisiko lebih besar dibandingkan dengan kadar $\mathrm{TLC} \leq 18.000 \mathrm{WBC} / \mathrm{mm}^{3}$. Tabel 4 menunjukkan bahwa dari 19 kejadian apendisitis dengan TLC $>18.000 \mathrm{WBC} / \mathrm{mm}^{3}$, sebanyak 15 kasus $(78,9 \%)$ termasuk dalam kasus perforasi. Sedangkan, dari 77 kejadian apendisitis dengan TLC $\leq 18.000 \mathrm{WBC} /$ $\mathrm{mm}^{3}$, hanya 18 kasus $(23,4 \%)$ saja yang termasuk dalam kasus perforasi. Nilai PR yang diperoleh adalah 3,3 yang menyatakan bahwa, kadar TLC $>18.000 \mathrm{WBC} / \mathrm{mm}^{3}$ berpengaruh terhadap apendisitis perforasi 3,3 kali lebih besar dibandingkan dengan apendisitis non-perforasi. Perbedaan risiko tersebut secara statistik berbeda dengan melihat nilai $\mathrm{X}^{2}$ yaitu 20,862 dan nilai $\mathrm{P}<0,05$ (Tabel 4).

Pada hasil uji statistik diperoleh hasil bahwa terdapat hubungan yang bermakna antara symptoms duration dengan kejadian apendisitis perforasi diamana symptoms duration $>24$ jam memiliki risiko lebih besar dibandingkan dengan symptoms duration $\leq 24$ jam. Tabel 5.5 menunjukkan dari 31 kejadian apendisitis dengan symptoms duration $>24$ jam, 22 kasus $(71,0 \%)$ diantaranya termasuk dalam kasus perforasi. Sedangkan, dari 65 kejadian apendisitis dengan symptoms duration $\leq 24$ jam hanya 11 kasus $(16,9 \%)$ saja yang termasuk dalam kasus perforasi. Besarnya nilai PR adalah 4,1 yang berarti symptoms duration $>24$ jam berpengaruh terhadap kejadian apendisitis perforasi 4,1 kali lebih besar dibandingkan dengan apendisitis non-perforasi. Perbedaan risiko tersebut secara statistik berbeda dengan melihat nilai $\mathrm{X}^{2}$ yaitu 27,177 dan nilai $\mathrm{P}<0,05$ (Tabel 5).

\section{PEMBAHASAN}

Berdasarkan penelitian yang telah dilakukan, diperoleh hasil bahwa usia memiliki hubungan yang signifikan dengan kejadian apendisitis perforasi. Hal ini sesuai dengan hasil uji statistik yang diperoleh yaitu nilai $\mathrm{X}^{2}=5,474, \mathrm{PR}=2,0$ dan nilai $\mathrm{P}<0,05$. Hasil penelitian yang diperoleh sesuai dengan hipotesis yang menyatakan bahwa pasien apendisitis usia 0-9 tahun atau di atas 49 tahun memiliki risiko terjadinya perforasi lebih besar dibandingkan dengan usia 10-49 tahun.

Berdasarkan literatur, semakin lama durasi dari gejala apendisitis berhubungan dengan terjadinya perforasi baik pada pasien dewasa ataupun anakanak. Pada pasien anak disebutkan durasi gejala akan semakin lama karena anak memiliki kesulitan dalam mengatakan keluhannya. Selain itu dikatakan semakin muda usia anak akan semakin tinggi mengalami resiko perforasi. Pada sebuah studi retrospektif, angka perforasi pada pasien dengan usia dibawah 1 tahun mendekati 100\% dan dibawah 5 tahun sebesar 69\%. Pada pasien anak, kejadian perforasi yang tinggi juga disebabkan oleh faktor anatomi dimana dinding apendikular yang lebih tipis dibandingkan dengan pasien dewasa, omentum yang lebih kecil sehingga tidak cukup mampu untuk mencegah penyebaran infeksi, dan sekum yang tidak dapat berdilatasi. ${ }^{8}$

Dibandingkan dengan kelompok usia yang lebih muda, pasien usia lanjut memiliki penyakit penyerta dan reaksi fisiologis tubuh yang lebih lamban sehingga menghasilkan tingkat morbiditas dan mortalitas yang lebih tinggi. Terjadinya perforasi pada pasien lansia diakibatkan oleh presentasi gejala yang sering tidak khas dan keterlambatan dalam mencari bantuan medis sehingga menyebabkan keterlambatan dalam penegakan diagnosis dan pengobatan. Keadaan ini disebabkan oleh sensasi nyeri pada pasien lansia lebih ringan dibandingkan pasien muda. Ini dipengaruhi oleh penurunan fungsi saraf dan kebiasaan mengkonsumsi penghilang rasa nyeri yang menyebabkan menurunnya sensasi nyeri. Berdasarkan penelitian Tantarattanapong et al. keterlambatan sampai di unit gawat darurat dalam durasi waktu lebih dari 24 jam sejak timbulnya gejala adalah faktor signifikan yang terkait dengan kejadian perforasi. faktor sosial juga berhubungan dengan kejadian ini, dimana pada pasien lansia yang tinggal sendiri menyebabkan risiko untuk menunda mencari layanan medis. ${ }^{9}$ Kejadian apendisitis perforasi pada 
lansia juga berhubungan dengan keadaan anatomi. Pada umumnya appendik vermiform pasien lansia dapat mengalami vaskular sklerosis, penyempitan lumen akibat fibrosis serta adanya infiltrat lemak pada lapisan muskular sehingga struktur apendik menjadi lemah dan mendorong terjadinya perforasi. ${ }^{10,11}$

Tingkat perforasi pada pasien apendisitis dibawah 6 tahun dapat mencapai 90\% sedangkan dibawah usia 5 tahun tingkat perforasi mencapai $82 \%$. Hal ini sejalan dengan penelitian yang dilakukan oleh Kanumba et al. yaitu angka perforasi mencapai $80 \%$ pada pasien apendisitis berusia 0-15 tahun dan diatas 60 tahun. Hal serupa juga ditemukan oleh Mick et al. (2006), yang menyatakan bahwa kasus apendisitis perforasi tinggi, yaitu sekitar $80 \%$ pada pasien usia dibawah 3 tahun dan usia diatas 60 tahun. ${ }^{12,13}$

Hasil penelitian yang diperoleh menunjukkan bahwa jenis kelamin memiliki hubungan yang bermakna terhadap kejadian apendisitis perforasi. Hal ini sesuai dengan hasil uji statistik yang diperoleh yaitu nilai $\mathrm{X}^{2}=8,800$ dan nilai $\mathrm{P}<0,05$. Hasil penelitian ini sesuai dengan hipotesis yaitu pasien apendisitis laki-laki memiliki risiko terjadinya perforasi lebih besar dibandingkan dengan perempuan.

Khalil \& Muqim menyebutkan, tingginya kejadian perforasi pada pasien apendisitis laki-laki disebabkan karena adanya perbedaan respon imun tubuh, namun perbedaan ini masih belum jelas diketahui. Pada penelitian Gajbhiye et al. disebutkan pula bahwa kondisi ini kemungkinan diakibatkan karena laki-laki lebih sering terpapar dengan lingkungan luar dan lebih sering mengalami perubahan pola makan, jika dibandingkan dengan perempuan. Hal ini juga dapat disebabkan karena pada umumnya laki-laki enggan untuk berobat ke rumah sakit, serta akibat adanya faktor sosial yaitu kebanyakan laki-laki tinggal sendiri sehingga berisiko terlambat untuk memperoleh pelayanan kesehatan. ${ }^{14-16}$

Sebuah penelitian yang dilakukan oleh Omari et al. mengenai faktor risiko perforasi pada pasien apendisitis akut, memperoleh hasil yaitu dari 87 pasien apendisitis perforasi sebanyak 46 orang (53\%) adalah laki-laki sedangkan sebanyak 41 orang (47\%) adalah perempuan. Hal serupa juga ditunjukkan oleh hasil penelitian Vaziri et al. (2013), yang menyatakan bahwa dari 38 pasien apendisitis perforasi sebanyak 24 orang $(70 \%)$ adalah lakilaki sedangkan sebanyak 12 orang (30\%) adalah perempuan. Studi lain mengenai kejadian perforasi pada pasien apendisitis akut, menunjukkan hasil yang sama yaitu dari 31 pasien apendisitis perforasi sebanyak 22 orang $(70,9 \%)$ adalah laki-laki sedangkan sebanyak 9 orang $(29,1 \%)$ adalah perempuan (Phiri, 2007). Penelitian oleh Sulu et al. (2010) juga menunjukkan hasil serupa yaitu pada kelompok pasien apendisitis perforasi, sebanyak 122 orang $(63,5 \%)$ adalah pasien laki-laki sedangkan sebanyak 70 orang $(36,5 \%)$ adalah perempuan., ${ }^{9,17,18}$

Berdasarkan penelitian yang telah dilakukan, dapat disimpulkan bahwa TLC dapat menjadi suatu prediktor terjadinya apendisitis perforasi. Hal ini sesuai dengan hasil statistik yang diperoleh yaitu nilai $\mathrm{X}^{2}=20,862, \mathrm{PR}=3,3$ dan nilai $\mathrm{P}<0,05$. Hasil penelitian yang diperoleh sejalan dengan hipotesis yang menyatakan bahwa pasien apendisitis dengan kadar TLC > $18.000 \mathrm{WBC} / \mathrm{mm}^{3}$ memiiki risiko terjadinya perforasi lebih besar dibandingkan dengan kadar TLC $\leq 18.000 \mathrm{WBC} / \mathrm{mm}^{3}$.

Nepal medical College Journal dan American Family Physician menyebutkan bahwa angka leukosit pada apendisitis perforasi lebih tinggi daripada apendisitis akut, disebabkan karena tingkat peradangan yang lebih parah terjadi pada apedisitis perforasi. Pada fase perforasi, apendik telah megalami ruptur, pecah atau berlubang dan pus yang terdapat didalam lumen apendik menyebar keluar menuju organ lain. Fase perforasi juga berhubungan dengan progresivitas invasi bakteri yang difasilitasi oleh sitotoksin bakteri. Jumlah bakteri yang terisolasi pada apendisitis perforasi adalah lima kali lebih besar dibandingkan dengan apendisitis akut. Keadaan ini kemudian dapat memicu terjadinya peritonitis serta menyebabkan bakteri berkembang dan menimbulkan infeksi yang lebih banyak. Akibatnya respon imun tubuh akan terangsang dengan menghasilkan lebih banyak leukosit atau neutrofil, yang berfungsi sebagai pertahanan terhadap agen patogen. ${ }^{19,20}$

Selain itu, Sack et al. juga menyatakan bahwa hitung leukosit mengalami peningkatan pada pasien apendisitis perforasi. Berdasarkan studinya, hal ini terjadi akibat peran bakteri yang merupakan penyebab apendisitis seperti bakteri E. coli atau Bacteroides fragilis dan adanya proses inflamasi yang mendasarinya. Faktor penyebab apendisitis seperti bakteri dan endotoksin berupa lipopolisakarida, dapat meningkatkan pelepasan sitokin yaitu Tumor Necrosis Factor a (TNF-a), Interleukin 1 (IL-1), dan IL-6. Interleukin 6 merupakan faktor utama dalam menginduksi sintesis protein pada fase akut yaitu sintesis C-Reactive Protein (CRP) dan asam $\alpha_{1}$-glikoprotein, serta mampu mendegranulasi neutrophilic dan menghambat apoptosis. Adanya perubahan sintesis protein ini dapat menimbulkan respon tubuh berupa tingginya kadar leukosit darah serta peningkatan aktivitas imun dan suhu tubuh. Dalam studi Sack et al. disebutkan pula bahwa konsentrasi IL-6 dapat dideteksi pada pasien dengan suspek apendisitis akut dan konsentrasi tertinggi ditemukan pada pasien apendisitis perforasi. ${ }^{21-23}$ 
Berdasarkan penelitian Pratiwi et al. mengenai akurasi nilai leukosit dalam menegakkan diagnosis setiap derajat apendisitis, diperoleh hasil bahwa nilai leukosit tertinggi ditemukan pada apendisitis perforasi yaitu sebesar $22.000 / \mathrm{mm}^{3}$ sedangkan nilai leukosit terendah ditemukan pada pasien apendisitis simpel yaitu sebesar $12.500 / \mathrm{mm}^{3}$. Pada hasil penelitian ini tampak peningkatan leukosit pada setiap derajat apendisitis. Penelitian Socea et al. juga menyimpulkan bahwa nilai leukosit meningkat pada penyakit berat dan secara signifikan meningkat tinggi pada kasus apendisitis perforasi. Hasil penelitian ini menyatakan bahwa leukosit lebih dari $16.920 \mathrm{WBC} / \mathrm{mm}^{3}$ menunjukkan adanya apendisitis perforasi. ${ }^{724}$

Hasil penelitian yang diperoleh menunjukkan bahwa symptoms duration memiliki hubungan yang bermakna dengan kejadian apendisitis perforasi. Hal ini ditunjukkan oleh hasil uji statistik yaitu nilai $\mathrm{X}^{2}=27,117, \mathrm{PR}=4,1$ dan $\mathrm{p}<0,05$. Hasil penelitian ini sesuai dengan hipotesis yang menyatakan bahwa pasien apendisitis dengan symptoms duration $>24$ jam memiliki risiko terjadinya perforasi lebih besar dibandingkan dengan symptoms duration $\leq 24 \mathrm{jam}$.

Lamanya durasi gejala yang terjadi pada kasus apendisitis perforasi berhubungan dengan beratnya penyakit dan lamanya durasi inflamasi yang terjadi. Studi Ruber, menyebutkan bahwa terjadinya apendisitis perforasi berhubungan dengan keterlambatan pasien memperoleh pelayanan kesehatan, sehingga menyebabkan durasi inflamasi terjadi lebih lama dan keadaan penyakit menjadi lebih berat, yang kemudian memicu terjadinya perforasi. Sebagian besar keterlambatan pasien memperoleh pelayanan kesehatan disebabkan oleh kurangnya akses rumah sakit, klinik, atau informasi dan akibat keterlambatan memperoleh pengobatan awal. Pada studi ini juga diperoleh hasil bahwa sebagian besar kejadian apendisitis perforasi terjadi saat sebelum pasien tiba di rumah sakit. ${ }^{14,25,26}$ Lamanya durasi inflamasi dan beratnya keadaan penyakit juga dipersulit oleh keterlambatan diagnosis apendisitis akibat manifestasi klinis yang tidak spesifik. ${ }^{14} \mathrm{Hal}$ lain yang dapat menjadi faktor lamanya durasi gejala yang dialami pasien apendisitis perforasi adalah faktor umur dan mekanisme terjadinya obstruksi. ${ }^{27}$

Busch et al. mengatakan bahwa insiden apendisitis perforasi secara signifikan akan meningkat apabila pasien megalami penundaan lebih dari 12 jam dalam memperoleh pelayanan kesehatan. Hasil penelitian tersebut sejalan dengan penelitian Larsen et al. (2013) yang mengatakan bahwa tidak terdapat kasus apendisitis perforasi pada symptoms duration kurang dari 12 jam, sedangkan kasus ini mencapai $10 \%$ dengan symptoms duration 18 jam dan mencapai $44 \%$ pada symptoms duration 36 jam. Penelitian
Dian et al. juga memperoleh hasil yaitu, dari 47 pasien apendisitis perforasi sebanyak 40 pasien $(85,1 \%)$ memiliki symptoms duration lebih dari 24 jam sedangkan sebanyak 7 pasien $(14,9 \%)$ memiliki symptoms duration kurang dari 24 jam. Hal ini sejalan dengan penelitian Singh et al. (2014) yang menunjukkan bahwa terdapat hubungan yang signifikan antara kejadian apendisitis perforasi dengan symptom duration lebih dari 72 jam. ${ }^{28-31}$

\section{SIMPULAN}

Berdasarkan hasil uji statistik tersebut dapat disimpulkan bahwa usia, jenis kelamin, TLC, dan symptoms duration bermakna signifikan sehingga dapat dijadikan faktor prediktor terjadinya apendisitis perforasi. Faktor prediktor ini sebaiknya diperhatikan untuk mencegah kejadian perforasi pada pasien apendisitis ataupun memberikan penanganan yang lebih cepat pada kasus perforasi.

\section{KONFLIK KEPENTINGAN}

Penulis menyatakan tidak terdapat konflik kepentingan terkait publikasi dari penelitian ini.

\section{PENDANAAN}

Penelitian ini tidak mendapat bantuan dana dari pemerintah ataupun lembaga swasta lainnya.

\section{DAFTAR PUSTAKA}

1. Hegazi, M.A \& Patel, T.A, Acute Amoebic Appendicitis: Case Report and Review of Parasitic Appendicitis. Journal of the Pediatric Infectious Diseases Society. 2013;2(1):80-81.

2. Indri UV, Karim D, Elita V. Hubungan Antara Nyeri, Kecemasan dan Lingkungan dengan Kualitas Tidur pada Pasien Post Operasi Apendisitis. JOM PSIK. 2014;1(2):1-2.

3. Tiono BG, Sudartana K, Widiana R. There is no difference of surgical site infection between single-dose and multiple-dose of prophylaxis antiobiotic in open appendectomy of non-perforated acute appendicitis. Bali Medical Journal. 2012;1(3):121-126

4. Sibuea SH. Perbedaan Antara Jumlah Leukosit Darah Pada Pasien Apendistis Akut Dengan Apendisitis Perforasi di RSUP DR. Kariadi Semarang. 2014. E-Journal Undip;2(1):8-21.

5. Rai R, Souza RC, Vijin SH, Aithala PS, Ramakrishna KP, Fernandes AM. An Evaluation of The Seasonal Variation in Acute Appendicitis. Journal of Evolution of Medical and Dental Sciences. 2014;3:257-58.

6. Bratton SL, Haberkern CM, Waldhausen JH. Acute Appendicitis Risks of Complications: Age and Medicaid Insurance. Pediatrics. 2000;106(1):75-77.

7. Socea B, Carap A, Rac-Albu M, Constantin V. The Value of Serum Bilirubin Level and of White Blood Cell Count as Severity Markers for Acute Appendicitis. 2013;108:830-34.

8. Gupta S. Neonatal Appendicitis with Perforation: A Case Report and Review. J Indian Assoc Pediatr Surg. 2005;10:173-174.

9. Omari J, et al. Acute appendicitis in the elderly: risk factors for perforation. World Journal of Emergency Surgery. 2014;9:6-12. 
10. Khorasani B, Pasha AG. Effects of Two New Risk Factors on Perforated and Non-Perforated Appendicitis. Journal of Biological Sciences. 2009;4(11): 1176-1178.

11. Petroianu A. Acute Appendicitis-Propedeutics and Diagnosis. Inflammatory Diseases - Immunopathology, Clinical and Pharmacological Bases. 2012:12(2):179-181.

12. Kanumba ES, Mabula JB, Rambau S, Chalya PL. Modified Alvarado Scoring System as a diagnostic tool for Acute Appendicitis at Bugando Medical Centre, Mwanza, Tanzania. BMC Surgery. 2011;11(4):2-5.

13. Mick NW, Peters JR, Egan D, Nadel ES, Walls R, Silvers S. Emergency Medicine, $2^{\text {nd }}$ ed, Lippincott williams \& Wilkins. Philadelphia; 2006.

14. Khalil J, Muqim R. Impact of Delay in Acute Appendicitis. Pak J Surg. 2010;26(1):32-34.

15. Gajbhiye AS, Dakhore SD, Meshram MM, Khathod AP. Perforated Appendicitis in Children. Journal of Dental and Medical Sciences. 2013;11(1): 10-15.

16. Sirikurnpiboon S, Amornpornchareon S. Factors Associated with Perforated Appendicitis in Elderly Patients in a Tertiary Care Hospital. Surgery Research and Practice. 2015;3(4):2-5.

17. Vaziri M, Pazouki A, Tamannaie Z, Maghsoudloo F, Pishgahroudsari M, Chaichian S. Comparison of PreOperative Bilirubin Level in Simple Appendicitis and Perforated Appendicitis. Medical Journal of The Islamic Republic of Iran. 2013;27(3):110-112.

18. Sulu B, Gunerhan Y, Palanci Y, Isler B, Caglayan K Epidemiological and Demographic Features of Appendicitis and Influences of Several Environmental Factors. Turkish Journal of Trauma \& Emergency Surgery. 2010;16(1):39-42.

19. Marisa JHI, Setiawan MR. Batas Angka Lekosit Antara Apendisitis Akut dan Apendisitis Perforasi di Rumah Sakit Umum Daerah Tugurejo Semarang Selama Januari 2009 - Juli 2011. Jurnal Kedokteran Muhammadiyah. 2012;1(1):3-7.

20. Chaudhary P, Kumar A, Saxena N, Biswal UC. Hyperbilirubinemia as a predictor of gangrenous/perforated appendicitis: a prospective study. Annals of gastroenterology. 2013;26:326-30.

21. Sack U, Biereder B, Elouahidi T, Bauer K, Keller T, Trobs RB. Diagnostic Value of Blood Inflammatory Markers for Detection of Acute Appendicitis in Children. BMC Surgery. 2006;6(15):3-8.
22. Livingston EH, Woodward WA, Sarosi GA, Haley RW. Disconnect Between Incidence of Nonperforated and Perforated Appendicitis. Annals of Surgery. 2007;245(6):887-891.

23. Atahan K, Ureyen O, Aslan E, Deniz M, Cokmez A, Gur S, et al. Preoperative Diagnostic Role of Hyperbilirubinaemia as a Marker of Appendix Perforation. The Journal of International Medical Research. 2011;39:611-616.

24. Pratiwi S, Arbi I, Lestari SM. Gambaran Hitung Leukosit Pre Operatif Pada Tiap-Tiap Tingkat Keparahan Apendisitis Akut Anak (Berdasarkan Klasifikasi Cloud) Di RSUD Arifin Achmad Provinsi Riau Periode Januari 2011-Desember 2012. E-Journal Unri. 2014;3:3-10.

25. Ruber M. Immunopathogenic Aspects of Resolving and Progressing Appendicitis. Faculty of Health of Sciences Linkoping University. 2012;3:63-65.

26. Nshuti R, Kruger D, Luvhengo TE. Clinical Presentation of Acute Appendicitis in Adults at the Chris Hani Baragwanath Academic Hospital. International Journal of Emergency Medicine. 2014;7(12):2-5.

27. Temple CL, Huchcroft SA, Temple WJ. The Natural History of Appendicitis in Adults A Prospective Study. Annals of Surgery. 1995;3:279-81.

28. Busch M, Gutzwiller FS, Kuettel SA, Metzger U, Zingg U. In-Hospital Delay Increase the Risk of Perforation in Adults with Appendicitis. World Journal of Surgery. 2011;35(7):1626-1633.

29. Larsen SJ, Lalla M, Thorup JM. The Influence of Age, Duration of Symptoms and Duration of Operation on Outcome After Appendicitis in Children. Danish Medical Journal. 2013;60(8):2-5.

30. Dian A, Ali A, Azam UF, Khan MM. Perforated Appendix-Our Local Experience. Rawal Medical Journal. 2011;36(2):3-5.

31. Singh M, Kadian Y, Rattan K, Jangra B. Complicated Appendicitis: Analysis of Risk Factors in Children. African Journal of Paediatric Surgery. 2014;11(2):109-113.

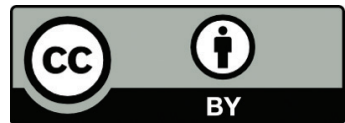

This work is licensed under a Creative Commons Attribution 